\title{
Changes in the physicochemical quality, functional properties, and actinidin content of kiwifruit (Actinidia chinensis) during postharvest storage
}

\author{
Seung-Hee Nam* \\ Department of Food Science and Technology and Functional Food Research Center, \\ Chonnam National University, Gwangju 61186, Korea
}

\section{후숙시기 동안 참다래의 품질, 기능성 및 액티니딘 함량 변화 조사}

\author{
남승희* \\ 전남대학교 식품공학과, 기능성연구센터
}

\begin{abstract}
Kiwifruit (Actinidia chinensis, Hayward) was stored at $25^{\circ} \mathrm{C}$ for $0 \sim 30$ days and investigated to find out the optimum storage time to obtain the best physical and functional properties for consumers' preference. Kiwifruits was stored at different time period $(0,5,10,15,20$, and 30 days) for investigating their physiochemical quality, nutritional components, and functional characteristics. Kiwifruits stored for 20 30 days showed the best physiochemical quality such as higher total acidity and proper firmness. They were also more enriched with dietary fibers, free sugar, and organic acid, although no significant changes were observed in crude protein, crude fat, and moisture content. For functional properties, kiwifruits stored for 20 days showed significantly higher contents of total phenolics, flavonoids, and actinidin. In addition, it showed stronger antioxidant activity, whitening effect, and proteolytic activity when compared with other samples. SDS-PAGE analysis showed the presence of actinidin enzyme in kiwifruits. These results indicated that the kiwifruits stored for 15 20 days possessed excellent quality and high concentrations of nutritional and functional compounds, which could be best for both fresh consumption and product processing
\end{abstract}

Key words : kiwifruit, postharvest storage, functional properties, actinidin content

\section{서 론}

참다래(Actinidia deliciosa)는 다래나무과(Acinidiaceae) 다래나무속(Acinidia)에 속하며 우리나라에서는 흔히 키위 라 부른다(1). 과육의 색에 따라 그린참다래, 골드키위, 레드 키위 등으로 분류하는데 전 세계적으로 가장 많이 재배되고 있는 것은 그린키위 품종이다(2). 우리나라에서는 전남에 서 많이 생산되고 기타 다른 남부지역에서도 재배되는데, 그동안 품질향상을 위한 여러 가지 노력이 행하여져 수입키

*Corresponding author. E-mail : namsh1000@hanmail.net Phone : 82-62-530-2140, FAX : 82-62-530-2146

Received 22 February 2016; Revised 29 March 2016; Accepted 4 April 2016.

Copyright (c) The Korean Society of Food Preservation. All rights reserved.
위보다 맛이 월등하다고 평가되고 있다(3).

참다래에는 vitamin C 함량이 $80 \sim 120 \mathrm{mg} \%$ 로 한 개의 섭취로도 하루 요구량을 충족 할 수 있고 vitamin $\mathrm{E}$ 와 섬유 소가 풍부하며, 나트륨이 적고 칼륨이 많아 고혈압 예방효 과가 있다고 알려져 있다 $(1,3)$. 또한 참다래에는 quinic acid, malic acid, citric acid 등의 유기산이 다량 함유되어 있어 특유의 풍미를 지니고 있으며 항산화 효과와 미백효과를 보인다고 보고되고 있다(4-5). 단백질 분해효소가 들어 있 어 가정이나 음식점에서 육류 요리에 참다래를 몇조각 첨가 하면 빛깔이 좋아지고 향기 또한 향상되며 육류 과다섭취로 일어나는 여러 가지 질병을 예방할 수가 있다고 알려져 있다(1,3). 특히 actinidin(EC3.4.22.14)은 SH기를 갖는 참다 래 단백질 분해효소인 thiol protease로 papain, ficin, bromelain과 유사하나 aromatic N-substitutes에 대한 $\mathrm{Kcat} / \mathrm{km}$ 값이 다른 것으로 보아 기질과 결합하는 부위가 
다를 것으로 보고되었다. 또한 actinidin은 3가지 isoforms이 존재하며 분자량은 $17 \mathrm{kDa}, 23 \mathrm{kDa}, 31 \mathrm{kDa}$ 을 갖는다고 보고되었다 $(6,7)$.

Climacteric fruit인 참다래는 후숙에 따라 total sugar나 soluble solids가 증가 하여 단맛이 증가하지만 펙틴질의 분해로 인하여 firmness가 감소하여 상처로 인한 상품가치 하락의 염려가 있다. 저장 기술의 발달로 출하시기의 조절 이나 저장기간의 연장은 가능하지만 climacteric rise후 급격 한 품질연화로 유통기간은 그리 길지 못하다(3). 최근, 수확 후 저장된 Heyward(Actinidia deliciosa) 또는 Hardy (Actinidia arguta and Actinidia purpurea) 키위의 품질 및 효능 변화에 대한 연구가 보고되었다. Heyward 키위를 $(A$ deliciosa) 수확 후 $0 \sim 5^{\circ} \mathrm{C}$ 에서 수개월 저장하며 품질 특성 및 비타민 $\mathrm{C}$ 와 페놀화합물량을 조사하였다. 이때 키위의 품질의 변화는 적었으며 firmness등의 차이가 없으나 비타 민 C 함량과 페놀화합물량은 공통적으로 크게 감소하거나 증가함을 보고하였다(8,9). Heyward와는 다르게 털이 없고 크기가 작아서 통째로 먹는 Hardy 키위는 동일한 저장기간 에서 14 일 이내에 수분이 크게 감소하며 firmness와 total acidity가 감소하는 경향을 보고하였다(10-12). 또한 비타민 $\mathrm{C}$ 함량과 페놀화합물량이 7일과 14 일째에 큰 폭으로 감소 하며 이후에는 유지되는 경향을 보였다. Hardy 키위는 저장 조건 향상을 위해 Calcium caseinate, chitosan 같은 edible coatings제를 이용한 연구가 수행되었다(11)

현재, 국내에서는 참다래의 저장성 향상에 관한 연구는 많이 이루어지고 있으나 수확 후 상온 보관된 참다래의 적정 후숙 시기에 에 관한 연구는 거의 없다. 이에 본 연구에 서는 국내에서 수확된 참다래의 상온 보관 시 품질 뿐 아니 라 영양 및 생리활성이 가장 높은 최적 후숙 기간을 구명하 여 소비자들에게 기호도와 기능성이 뛰어난 참다래를 섭취 하는데 도움을 주고자 한다.

\section{재료 및 방법}

\section{실험재료}

본 연구에서 재료로 사용한 참다래는 '헤이워드(Actinidia chinensis Planch cv. Hayward) '품종으로 전남 해남군 삼산 면 소재 농가에서 재배하여 2012년 11월중 에 성숙도가 8.0 9.0\% soluble solids 인 것을 선발, 수확하였다. $100 \mathrm{~g}$ 내외의 과실 100 개씩을 플라스틱 상자에 넣은 후 상대습도 $85 \%$ 와 $0 \sim 4{ }^{\circ} \mathrm{C}$ 로 조정한 저장고에서 3 개월간 저장 된 것을 상온에서 0 일, 5 일, 10 일, 15 일, 20 일, 및 30 일 보관 후 분석에 사용 하였다. 일정기간 상온 $\left(20 \sim 25^{\circ} \mathrm{C}\right)$ 저장된 과실의 물리 적 특성, 수분함량, 유리당, 유기산 함량은 생과실을 사용하 였고 영양성분 함량 및 생리활성 조사는 과실을 동결건조 후 분말화 하여 실험에 사용하였다. 사용된 시약으로는
Folin-ciocalteau's phenol reagent, gallic acid, naringin, 1,1-diphenyl-2-picryl hydrazyl(DPPH), 2,2'-azino-bis(3ethylbenzothiazoline-6-sulfonic acid)(ABTS), potassium persulfate, tyrosinase, ferrozine, potassium ferricyanide, sodium nitrite 등으로 Sigma-Aldrich(St. Louis, MO, USA)에서 구입하였 고 그 외에 사용된 시약은 특급 및 일급을 구입하여 사용하 였다.

\section{물리적 특성}

총산은 $0.1 \mathrm{~N}-\mathrm{NaOH}$ 로 적정하여 citric acid로 환산하였고, 당도는 Abbe refractometer(Atago 501-DS, Tokyo, Japan)로 측정하였으며, 색도는 색차계(Minolta CT-310, Tokyo, Japan)를 이용하여 Hunter values $(\mathrm{L}, \mathrm{a}$ 및 $\mathrm{b})$ 를 측정하였다. 경도(firmness)는 TA-XT2 texture analyzer(Stable Micro Systems Texture Technologies, Scarsdale, NY, USA)를 이용 하여 껍질이 제거된 과실을 $8 \mathrm{~mm}$ 직경 팁을 이용해 처리별 10 개 과실을 측정하였다(13).

\section{일반성분 분석}

일반성분은 $\mathrm{AOAC}$ 방법(14)에 따라 다음과 같이 측정하 였다. 수분함량은 $105^{\circ} \mathrm{C}$ 건조 후 함량을 측정하여 산출하였 고, 조단백질은 auto-Kjeldahl법, 조지방은 Soxhlet 추출장치 로 추출하여 측정하였고, 조회분은 $550^{\circ} \mathrm{C}$ 직접 회화법으로 측정하였으며, 조식이섬유는 효소(Megazyme kit, Chicago, $\mathrm{IL}, \mathrm{USA}$ )를 이용해 총식이섬유와 수용성, 불용성 식이섬유 로 나타내었다 (15).

\section{유리당 정량}

유리당 분석은 각 시료를 마쇄한 후 Choi 등이 행한 방법 (16)으로 유리당 획분을 얻은 다음 $0.22 \mu \mathrm{m}$ membrane filter 로 여과한 후 Sep-pak $\mathrm{C}_{18}$ 로 색소 및 단백질 성분을 제거한 다음 HPLC(Hewlett packard 1100 series, Sandiego, CA, USA)로 분석하였다. column은 Aminex carbohydrate HPX42-A를 사용하였고, solvent와 flow rate는 $80 \%$ acetonitrile과 $1.0 \mathrm{~mL} / \mathrm{min}$, detector는 RI로 하였고, column 온도와 injection volume은 각각 $40^{\circ} \mathrm{C}$ 와 $20 \mu \mathrm{L}$ 이었다.

\section{유기산 정량}

유기산의 분석은 시료 $50 \mathrm{~g}$ 에 증류수 $50 \mathrm{~mL}$ 를 가하여 homogenizer로 마쇄하고 원심분리 $(8,000 \mathrm{rpm}, 10$ 분)하여 얻 은 상층액 중 일부를 $0.45 \mu \mathrm{m}$ membrane filter와 Sep-pak $\mathrm{C}_{18}$ cartridge에 통과시킨 후 HPLC(Shimadzu SPD 10A, Tokyo, Japan)로 분석하였으며, column은 $\mu$-Bondapak $\mathrm{Cl}_{18}(3.9 \mathrm{~mm}$ i.d. $\times 30 \mathrm{~cm})$ 을 사용하였으며 $0.5 \% \mathrm{KH}_{2} \mathrm{PO}_{4}$ 를 용매로 하고, UV detector $214 \mathrm{~nm}$ 로 하였다. 유기산 각각의 농도는 표준물질로 검량선을 작성하여 환산하였다(17). 
총페놀과 총플라보노이드 함량 측정

총페놀 함량은 Cui 등(18)의 방법을 이용하여 측정하였 다. 각 건조 시료 $(25 \mathrm{mg} / \mathrm{mL})$ 에 $80 \%$ 에탄올 환류 추출액 $0.1 \mathrm{~mL}$ 에 증류수 $1.9 \mathrm{~mL}$ 와 Folin-Ciocalteau's phenol reagent $0.2 \mathrm{~mL}$ 를 가하여 실온에서 3 분간 반응시킨 후 포화 $\mathrm{Na}_{2} \mathrm{CO}_{3}$ 용액 $0.4 \mathrm{~mL}$ 와 증류수 $1.9 \mathrm{~mL}$ 를 가하여 혼합하였다. 이것을 실온에서 2시간 반응 시킨 후 $725 \mathrm{~nm}$ (Smart Plus SP$1900 \mathrm{PC}$, Seoul, Korea)에서 흡광도를 측정하였으며 표준물 질로는 gallic acid를 이용하여 농도별 표준곡선을 작성한 후 총 폴리페놀 함량을 gallic acid 기준으로 환산 하였다. 총플라보노이드 함량은 aluminum-chloride colorimetric $\operatorname{method}(19)$ 를 이용하여 $506 \mathrm{~nm}$ 에서 측정하였으며 표준물 질로는 quercetin을 이용하여 농도별 표준곡선을 작성한 후 총 플라보노이드 함량을 quercetin 기준으로 환산하였다.

DPPH radical 소거능, NO 소거능, Tyrosinase 저해 효과 동결건조 후 분말화한 참다래 시료 $(25 \mathrm{mg} / \mathrm{mL})$ 에 초순수 물을 첨가해 3시간 Soxhlet 추출한 후 여과지(Whatman filter paper No. 1)로 여과 한 후 열수 추출물은 DPPH radical 소거능, NO 소거능, Tyrosinase 저해 효과 측정에 사용하였 다. 시료 용액의 DPPH radical 소거능은 Blois의 방법(20)에 준하여 측정 하였다. 각 시료용액 $0.3 \mathrm{~mL}$ 에 $0.1 \mathrm{mM} \mathrm{DPPH}$ 용액 $2 \mathrm{~mL}$ 를 가하여 혼합하고 실온에서 30 분간 반응시킨 후 $517 \mathrm{~nm}$ 에서 흡광도를 측정하여 시료용액 첨가군과 무첨 가군 간의 흡광도 비(\%)로 나타 내었다. 아질산염 소거능 (NO scavenging activity)은 Kato 등(21)의 방법을 변형하여 측정 하였다. 각 시료용액 $0.5 \mathrm{~mL}$ 에 $1 \mathrm{mM}$ sodium nitrite $0.1 \mathrm{~mL}$ 를 가하고 $0.1 \mathrm{~N} \mathrm{HCl}(\mathrm{pH} 1.2) 0.4 \mathrm{~mL}$ 를 가한 다음 $37^{\circ} \mathrm{C}$ 에서 1 시간 동안 반응시켰다. 그 후 $2 \%$ acetic acid 2 $\mathrm{mL}$ 와 Griess 시약 $0.4 \mathrm{~mL}$ 를 가하고 혼합하여 실온에서 15 분 간 방치한 다음 $520 \mathrm{~nm}$ 에서 흡광도를 측정하여 시료용액 첨가군과 무첨가군 간의 흡광도 비(\%)로 나타내었다. Tyrosinase 저해 효과는 Chung(5)의 방법을 변형하여 측정 하였다. 기질로서 $10 \mathrm{mM}$ L-DOPA $0.2 \mathrm{~mL}$ 와 $0.175 \mathrm{M}$ phosphate buffer(pH 6.8) $0.2 \mathrm{~mL}$ 에 시료용액 $0.5 \mathrm{~mL}$ 를 가하 여 잘 혼합한 다음 mushroom tyrosinase $(110 \mathrm{U} / \mathrm{mL}) 0.1 \mathrm{~mL}$ 를 가하였다. 이 혼합액을 $35^{\circ} \mathrm{C}$ 에서 2 분간 반응시킨 후 475 $\mathrm{nm}$ 에서 흡광도를 측정하여 시료용액 첨가군과 무첨가군 간의 흡광도 비(\%)로 나타내었다.

\section{액티니딘 추출 및 정량}

후숙 기간별 과실은 껍질은 벗긴 후 동결건조 및 마쇄하 여 $(10 \mathrm{~g})$ 추출버퍼 $200 \mathrm{~mL}(10 \mathrm{mM}$ cysteine, $1 \mathrm{mM}$ EDTA, $10 \mathrm{mM}$ sodium phosphate, $\mathrm{pH} 6.5$ )에 $4^{\circ} \mathrm{C}, 200 \mathrm{rpm}$ 에서 1 시간 추출하였다(22). 추출액을 $4{ }^{\circ} \mathrm{C}$ 에서 $15,000 \times \mathrm{g}$ 에서 30 분간 원심분리(Avan-Tr J-E, Beckman Coulter, Indianapolis, $\mathrm{IN}, \mathrm{USA}$ )하여 잔유물을 제거하고 상등액을 획득하였다.
상등액은 여과지와 $0.45 \mu \mathrm{M}$ membrane filter로 $4{ }^{\circ} \mathrm{C}$ 에서 순차적으로 여과하여 10 배 감압 농축해 참다래효소 조추출 액으로 사용하였다. 효소 조추출액은 $(0.5 \mathrm{~g} / \mathrm{mL})$ 단백질량 을 protein determination kit(Pierce Chemical Co., St. Louise, $\mathrm{MO}, \mathrm{USA}$ )를 이용해 정량 후 $20 \mu \mathrm{g}$ 단백질을 $12 \%$ discontinous SDS-PAGE를 통해 분석하였다. 참다래에 함유 된 cysteine proteases actinidin의 함량은 3 가지 크기를 지니 는 actinidin 단백질 $(17 \mathrm{kDa}, 23 \mathrm{kDa}, 31 \mathrm{kDa})$ 을 크기별로 확인 후 함유된 밀도를 NIH program(Scion corporation) 측 정하여 $\%$ 를 $\mu \mathrm{g}$ 으로 환산, 합하여 최종 actinidin 함량을 구하였다 $(6,7)$.

참다래추출액의 단백질 분해효과 조사

참다래 조효소의 단백질 분해효과는 Quanti-protease assay kit(Thermo scientific \#23263, Sandiego, CA, USA)를 이용해 microplate reader(Biotek Powerwave, Winooski, VT, $\mathrm{USA}$ )로 $450 \mathrm{~nm}$ 에서 흡광도를 측정되었다(23). Succinlyated casein 기질용액 $100 \mu \mathrm{L}, 1 \mathrm{mg} / \mathrm{mL}$ 와 참다래 조효소액(50 $\mu \mathrm{L})$ 를 혼합했다. 완충용액 $100 \mu \mathrm{L}(50 \mathrm{mM}$ sodium borate buffer, $\mathrm{pH}$ 8.5) 와 발색시약 $\operatorname{TNBSA}(2,4,6$-trinitrobenzene sulfonic acid) $50 \mu \mathrm{L}$ 를 혼합 후 20 분 후에 $450 \mathrm{~nm}$ 에서 흡광도 를 특정하였다. 이때 1 unit $(\mathrm{U}$ or $\Delta \mathrm{A} / \mathrm{min})$ 효소가 첨가되지 않은 대조구와 비교해 1 분간 0.001 흡광도가 증가된 효소량 을 나타낸다.

\section{관능평가}

전남농업기술원 실험원 중 15 명을 관능검사요원으로 선 발하여 시료의 외관(appearance), 향(flavor), 떫은 뒷맛 (astringency of aftermouth), 전체적기호도(overall acceptability) 에 대해 9점 채점법으로(1=매우 나쁨, 9= 매우 좋은) 평가하 였다.

\section{통계처리}

모든 자료는 3 반복 측정하여 평군과 표준편차를 계산하 였고 각 군간 차이의 통계적 유의성은 Statistical Analysis System(SAS) Package를 이용하여 분산분석을 실시하였으 며, Duncan의 다중범위 검정법(Duncan's multiple range test)으로 유의성을 검정하였다.

\section{결과 및 고찰}

\section{후숙 참다래의 품질 특성}

참다래를 후숙 시키기 위해 상온 $\left(20 \sim 25^{\circ} \mathrm{C}\right)$ 에서 0 일, 5 일, 10 일, 20 일, 및 30 일 간 방치 후 각 기간별로 과실의 가용성 고형분 함량(soluble solids), 적정산도(total acidity), 경도 (firmness) 및 색도(Hunter's value)를 측정하였다(Table 1). 
Table 1. Physicochemical properties of kiwifruit during postharvest storage

\begin{tabular}{|c|c|c|c|c|c|c|}
\hline \multirow{2}{*}{$\begin{array}{l}\text { Storage periods } \\
\text { (Days) }\end{array}$} & \multirow{2}{*}{$\begin{array}{l}\text { Soluble solids } \\
\text { ( }{ }^{\circ} \text { Brix) }\end{array}$} & \multirow{2}{*}{$\begin{array}{l}\text { Total acidity } \\
(\%)\end{array}$} & \multirow{2}{*}{$\begin{array}{l}\text { Firmness } \\
(\mathrm{g})\end{array}$} & \multicolumn{3}{|c|}{ Hunter's value } \\
\hline & & & & $\mathrm{L}$ & a & $\mathrm{b}$ \\
\hline 0 & $11.0 \pm 0.45^{\mathrm{el})}$ & $1.55 \pm 0.04^{\mathrm{a}}$ & $520 \pm 19.7^{\mathrm{a}}$ & $60.7 \pm 3.5^{\mathrm{a}}$ & $-12.2 \pm 1.5^{\mathrm{a}}$ & $32.5 \pm 2.7^{c}$ \\
\hline 5 & $12.4 \pm 0.23^{\mathrm{d}}$ & $1.42 \pm 0.03^{b}$ & $396 \pm 17.2^{b}$ & $59.9 \pm 3.7^{\mathrm{a}}$ & $-12.7 \pm 2.5^{\mathrm{a}}$ & $34.3 \pm 1.5^{b}$ \\
\hline 10 & $13.3 \pm 0.10^{\mathrm{d}}$ & $1.30 \pm 0.06^{b}$ & $322 \pm 5.2^{\mathrm{c}}$ & $56.7 \pm 2.2^{\mathrm{b}}$ & $-12.4 \pm 2.2^{\mathrm{a}}$ & $34.4 \pm 0.6^{b}$ \\
\hline 15 & $14.3 \pm 0.33^{\mathrm{c}}$ & $1.11 \pm 0.04^{c}$ & $225 \pm 9.0^{\mathrm{d}}$ & $56.5 \pm 2.0^{b}$ & $-11.6 \pm 0.7^{b}$ & $35.4 \pm 2.5^{\mathrm{b}}$ \\
\hline 20 & $14.8 \pm 0.17^{\mathrm{b}}$ & $1.02 \pm 0.03^{c}$ & $181 \pm 5.2^{\mathrm{e}}$ & $56.3 \pm 1.7^{\mathrm{b}}$ & $-10.8 \pm 0.5^{c}$ & $38.8 \pm 1.4^{\mathrm{ab}}$ \\
\hline 30 & $15.2 \pm 0.15^{\mathrm{a}}$ & $1.00 \pm 0.07^{\mathrm{c}}$ & $122 \pm 5.6^{\mathrm{e}}$ & $49.8 \pm 1.2^{c}$ & $-10.7 \pm 0.7^{\mathrm{c}}$ & $42.4 \pm 1.1^{\mathrm{a}}$ \\
\hline
\end{tabular}

${ }^{1)}$ Means in a column followed by the same letter are not significantly different $(\mathrm{p} \leq 0.05)$ by Duncan's test.

가용성 고형분 함량은 $12{ }^{\circ} \mathrm{Brix}$ 에서 30 일 후에 $15.2^{\circ} \mathrm{Brix}$ 까지 증가하였으며, 이는 저장 중에 성숙이 진행되어 전분 이 가수분해 되어 당 함량이 증가된 결과(24)에 의한 것으로 생각되었다. 산 함량은 당도와는 반대로 저장초기에 초기 에 1.55 에서 15 일째는 1.11 로 소량 감소하였으며 30 일까지 큰 변화는 없었다. 또한 $\mathrm{Kim}$ 과 $\mathrm{Ko}(25)$ 는 Hayward 품종 참다래의 적정산도를 $1.2 \sim 1.4 \%$ 로 유사한 수치를 보고하였 다. 색도 중 밝기를 나타내는 L값은 60.7 49.8로, 적녹도를 나타내는 a값은 -12.2 -10.7로 기간이 길수록 감소하였으며 황청도를 나타내는 $\mathrm{b}$ 값은 $32.5 ~ 42.4$ 로 점차 증가하였다. 경도는 저장초기에 520 에서 15 째까지 급격히 감소하였으 며 20 일 이후부터는 $23 \%$ 34\%로 조직이 연화되는 것을 알 수 있었다. 유사한 결과로, Park 등(26)은 Hayward 품종 참다래를 저장시 참다래 과실경도가 저장초기에 수확기 경도의 $20 \%$ 까지 감소된 후 서서히 감소되어 연화가 진행된 다고 보고 하였다.

\section{후숙 참다래의 일반적 성분}

기간별 상온 $\left(20 \sim 25^{\circ} \mathrm{C}\right)$ 후숙 된 참다래의 일반성분을 분 석한 결과(Table 2 ), 수분과 조단백질 함량은 $87 \% ~ 85 \%$, $5.9 \sim 6.2 \%$ 로 저장기간별 차이가 없었으며, 조회분과 조지방 함량은 5 일째에 $1.13 \%, 5.27 \%$ 로 각각 증가한 후 이후에는 큰 차이가 없었으며 통계학적으로 유의하지는 않았다. Lee 등(27)은 키위의 수분은 $83.7 \%$, 조지방 $4.37 \%$, 조단백
$4.91 \%$ 로 보고하여 수분, 조지방, 조단백 성분은 비슷한 결 과를 보였으나 조회분 함량은 본 실험의 결과와 큰 차이를 보였다. 키위에는 과실 중 식이섬유 함량이 높게 함유되 있으며 이중 불용성 식이섬유는 장내운동을 도와 소화흡수 에 도움이 되며 수용성 식이섬유는 체내 지방대사를 촉진시 켜 심장질환예방에 효과가 높다고 보고되어 있다(28). 효소 를 이용한 식이섬유 분석결과, 0 일째 $17.2 \%$ 에서 조금씩 증가하다가 10 일 이후와 20 일 이후에 증가폭이 컸으며 이런 경향은 수용성 식이섬유와 불용성 식이섬유 함량에서 도 유사하였다. 불용성 과 수용성 식이섬유는 전체 식이섬 유의 35 40\%, 8 10\%를 각기 차지하였다. Leontowicz등 (28)의 보고에 따르면, 키위에는 품종별로 $12.1 ~ 25.8 \%$ 의 총식이섬유를 함유하며 이중 $50 \sim 75 \%$ 가 불용성 식이섬유 로 구성되어 있다고 보고 하였다. 본 연구에서는 15 일 이후 에 식이섬유함량이 증가 하였는데, 특히 수용성 식이섬유 함량의 증가가 두드러졌다.

후숙 참다래의 유리당과 유기산 성분

기간별 후숙된 참다래에 함유되어 있는 유리당과 유기산 을 분석한 결과는 Table 3 과 4 와 같다. 즉, 참다래에는 총 3종류의 유리당이 존재하고 있으며, 그 종류는 fructose, glucose, 및 sucrose였고, 그 함량은 각각 $2.77 \%, 2.67 \%$, 및 $0.47 \%$ 로 나타났다. 3 가지 유리당 모두 후숙 기간이 길수록 함량이 증가 하였으며 특히 20일 이후에 모두 급격히 증가

Table 2. Proximate analysis of kiwifruit during postharvest storage

\begin{tabular}{cccccccc}
\hline $\begin{array}{c}\text { Storage periods } \\
\text { (Days) }\end{array}$ & $\begin{array}{c}\text { Moisture } \\
(\%)\end{array}$ & $\begin{array}{c}\text { Crude ash } \\
(\%)\end{array}$ & $\begin{array}{c}\text { Crude protein } \\
(\%)\end{array}$ & $\begin{array}{c}\text { Crude fat } \\
(\%)\end{array}$ & $\begin{array}{c}\text { Total dietary } \\
\text { fibers }(\%)\end{array}$ & $\begin{array}{c}\text { Insoluble fibers } \\
(\%)\end{array}$ & $\begin{array}{c}\text { soluble fibers } \\
(\%)\end{array}$ \\
\hline 0 & $87.2 \pm 1.81$ & $0.55 \pm 0.09^{\mathrm{bl})}$ & $5.92 \pm 0.38$ & $4.65 \pm 0.35^{\mathrm{b}}$ & $17.3 \pm 1.07^{\mathrm{c}}$ & $8.30 \pm 0.17^{\mathrm{c}}$ & $1.52 \pm 0.45^{\mathrm{b}}$ \\
5 & $86.0 \pm 1.10$ & $1.13 \pm 0.26^{\mathrm{a}}$ & $5.94 \pm 0.10$ & $5.27 \pm 0.12^{\mathrm{a}}$ & $18.8 \pm 1.76^{\mathrm{c}}$ & $8.40 \pm 0.26^{\mathrm{c}}$ & $1.54 \pm 0.35^{\mathrm{b}}$ \\
10 & $85.9 \pm 2.35$ & $1.23 \pm 0.15^{\mathrm{a}}$ & $6.02 \pm 0.21$ & $5.31 \pm 0.26^{\mathrm{a}}$ & $22.2 \pm 0.76^{\mathrm{b}}$ & $9.95 \pm 0.25^{\mathrm{b}}$ & $1.61 \pm 0.13^{\mathrm{b}}$ \\
15 & $85.8 \pm 2.94$ & $1.25 \pm 0.19^{\mathrm{a}}$ & $6.04 \pm 0.40$ & $5.43 \pm 0.35^{\mathrm{a}}$ & $24.5 \pm 0.55^{\mathrm{ab}}$ & $10.53 \pm 0.85^{\mathrm{b}}$ & $1.82 \pm 0.21^{\mathrm{b}}$ \\
20 & $85.3 \pm 2.66$ & $1.25 \pm 0.17^{\mathrm{a}}$ & $6.06 \pm 0.30$ & $5.44 \pm 0.35^{\mathrm{a}}$ & $26.9 \pm 2.07^{\mathrm{a}}$ & $12.52 \pm 0.55^{\mathrm{a}}$ & $2.68 \pm 0.20^{\mathrm{a}}$ \\
30 & $85.2 \pm 1.25$ & $1.31 \pm 0.20^{\mathrm{a}}$ & $6.21 \pm 0.21$ & $5.68 \pm 0.16^{\mathrm{a}}$ & $27.4 \pm 2.45^{\mathrm{a}}$ & $12.85 \pm 0.85^{\mathrm{a}}$ & $2.79 \pm 0.26^{\mathrm{a}}$ \\
\hline
\end{tabular}

\footnotetext{
${ }^{1)}$ Means in a column followed by the same letter are not significantly different $(\mathrm{p} \leq 0.05)$ by Duncan's test.
} 
Table 3. Free sugar contents of kiwifruit during postharvest storage

\begin{tabular}{ccccc}
\hline $\begin{array}{c}\text { Storage periods } \\
\text { (Days) }\end{array}$ & Sucrose & Glucose & Fructose & Total \\
\cline { 2 - 5 } & $(\%)$ & $(\%)$ & $(\%)$ & $(\%)$ \\
\hline 0 & $0.47 \pm 0.05^{\mathrm{cl})}$ & $2.67 \pm 0.07^{\mathrm{b}}$ & $2.77 \pm 0.09^{\mathrm{e}}$ & $5.91 \pm 0.11^{\mathrm{d}}$ \\
5 & $0.53 \pm 0.04^{\mathrm{c}}$ & $2.82 \pm 0.04^{\mathrm{b}}$ & $3.17 \pm 0.07^{\mathrm{d}}$ & $6.52 \pm 0.12^{\mathrm{c}}$ \\
10 & $0.62 \pm 0.05^{\mathrm{c}}$ & $2.83 \pm 0.09^{\mathrm{b}}$ & $3.34 \pm 0.09^{\mathrm{cd}}$ & $6.79 \pm 0.07^{\mathrm{c}}$ \\
15 & $0.87 \pm 0.09^{\mathrm{ab}}$ & $2.93 \pm 0.09^{\mathrm{b}}$ & $3.87 \pm 0.12^{\mathrm{c}}$ & $7.67 \pm 0.07^{\mathrm{b}}$ \\
20 & $1.12 \pm 0.07^{\mathrm{a}}$ & $3.10 \pm 0.12^{\mathrm{a}}$ & $4.35 \pm 0.08^{\mathrm{b}}$ & $8.57 \pm 0.09^{\mathrm{a}}$ \\
30 & $1.09 \pm 0.07^{\mathrm{a}}$ & $3.11 \pm 0.11^{\mathrm{a}}$ & $4.42 \pm 0.09^{\mathrm{a}}$ & $8.62 \pm 0.09^{\mathrm{a}}$ \\
\hline
\end{tabular}

${ }^{1}$ Means in a column followed by the same letter are not significantly different $(p \leq 0.05)$ by Duncan's test.

하는 경향을 보였다. 유리당 함량은 sucrose>fructose> glucose 순으로 나타났으며 전체 함량은 0일째 $5.91 \%$ 에서 20 일째 $8.8 \%$ 로 점차 증가하였다. Matsumoto 등(29) 과 Jeoung 등(24)은 그린키위와 골드키위의 유리당 함량을 측 정한 결과, 함량은 fructose, glucose, sucrose 순으로 유사한 결과를 보고하였으며, $\mathrm{Kim}$ 과 $\mathrm{Ko}(25)$ 에 의하면, 참다래 (Hayward)에는 대략 fructose가 2.4 3.4\%, glucose가 2.1 2.8\%, sucrose가 0.5 0.9\% 함유되어 있다고 보고하였 다. 또한 그린키위의 보관 시 5 일째부터 유리당의 함량이 증가하여 숙성기간이 경과함에 따라 유리당의 함량이 증가 하는 것으로 보고하였다(24,29).

과실의 신맛은 대체로 유기산의 함량에 의해 좌우되며 과실에는 주로 citric acid와 malic acid가 주가 된다. 주로 생육초기에는 malic acid량이 peak에 도달하고 생육이 진행 됨에 따라 citric acid가 증가하며 수확기가 되면 malic acid 의 두배 다량 증가된다. 키위는 다른 과실과 다르게 페놀화 합물의 전구체가 되는 quinic acid를 다량 함유하고 있음 (30). 참다래에 함유된 주요 유기산은 quinic acid, citric acid, malic acid, 및 ascorbic acid로(Table 4), 그 함량은 각각 865 $\mathrm{mg} / 100 \mathrm{~g}, 577 \mathrm{mg} / 100 \mathrm{~g}, 225 \mathrm{mg} / 100 \mathrm{~g}$ 및 $55 \mathrm{mg} / 100 \mathrm{~g}$

Table 4. Organic acids contents of kiwifruit during postharvest storage

\begin{tabular}{cccccc}
\hline \multirow{2}{*}{$\begin{array}{c}\text { Storage periods } \\
\text { (Days) }\end{array}$} & Quinic acid & $\begin{array}{c}\text { Citric } \\
\text { acid }\end{array}$ & $\begin{array}{c}\text { Malic } \\
\text { acid }\end{array}$ & $\begin{array}{c}\text { Ascorbic } \\
\text { acid }\end{array}$ & Total \\
\cline { 2 - 6 } & $(\mathrm{mg} / 100 \mathrm{~g})$ & $(\mathrm{mg} / 100 \mathrm{~g})$ & $(\mathrm{mg} / 100 \mathrm{~g})$ & $(\mathrm{mg} / 100 \mathrm{~g})$ & $(\mathrm{mg} / 100 \mathrm{~g})$ \\
\hline 0 & $865 \pm 38^{\mathrm{al})}$ & $577 \pm 15^{\mathrm{a}}$ & $225 \pm 12^{\mathrm{a}}$ & $55.0 \pm 8.7^{\mathrm{a}}$ & $1722 \pm 28^{\mathrm{a}}$ \\
5 & $858 \pm 36^{\mathrm{a}}$ & $572 \pm 21^{\mathrm{a}}$ & $215 \pm 17^{\mathrm{ab}}$ & $54.8 \pm 9.7^{\mathrm{a}}$ & $1700 \pm 56^{\mathrm{ab}}$ \\
10 & $839 \pm 41^{\mathrm{b}}$ & $559 \pm 22^{\mathrm{b}}$ & $213 \pm 10^{\mathrm{ab}}$ & $54.5 \pm 6.7^{\mathrm{a}}$ & $1666 \pm 45^{\mathrm{b}}$ \\
15 & $836 \pm 18^{\mathrm{b}}$ & $558 \pm 23^{\mathrm{b}}$ & $211 \pm 19^{\mathrm{ab}}$ & $50.8 \pm 0.7^{\mathrm{b}}$ & $1655 \pm 32^{\mathrm{b}}$ \\
20 & $794 \pm 21^{\mathrm{c}}$ & $529 \pm 13^{\mathrm{c}}$ & $209 \pm 15^{\mathrm{b}}$ & $50.8 \pm 2.7^{\mathrm{b}}$ & $1583 \pm 118^{\mathrm{c}}$ \\
30 & $785 \pm 16^{\mathrm{c}}$ & $524 \pm 9^{\mathrm{c}}$ & $205 \pm 23^{\mathrm{b}}$ & $49.3 \pm 4.7^{\mathrm{b}}$ & $1563 \pm 97^{\mathrm{d}}$ \\
\hline
\end{tabular}

${ }^{1}$ Means in a column followed by the same letter are not significantly different $(\mathrm{p} \leq 0.05)$ by Duncan's test.
순이었다. Jeoung 등(24)에 의하면, 참다래(Hayward)에는 대략 quinic acid가 $665 \mathrm{mg} / 100 \mathrm{~g}$, citric acid가 $482 \mathrm{mg} / 100$ $\mathrm{g}$, malic acid가 $162 \mathrm{mg} / 100 \mathrm{~g}$ 함유되어 있다고 보고하였다. 특히 quinic acid 와 citric acid 가 차지하는 비율은 $80 \%$ 이상으로 참다래에 함유된 유기산은 이 두 가지가 대부분이 라 할 수 있다. 전체 유기산 함량은 0 일째 $1.7 \%$ 에서 20 일 이후에는 $1.5 \%$ 로 후숙 기간이 증가할수록 유기산 함량이 감소하는 경향을 보였고 이는 적정산도가 후숙 기간이 증가 할수록 감소하는 경향과 일치하였다(Table 1). Youn과 Choi(31)의 보고에 의하면 참다래의 유기산 함량은 대략 1.5 2.5\%로 수확시기에 따라 유기산 함량이 변화가 있으며 숙성이 진행됨에 따라 citric acid 및 malic acid가 다소 감소 하여 유사한 결과를 나타냈다. 또한 참다래 유기산은 저온 보다는 고온에서 손실이 많으며 처리나 저장 시간이 길어질 수록 총 유기산 함량이 감소한다고 보고하였다. $\mathrm{Kim}$ 과 $\mathrm{Ko}(25)$ 는 참다래의 유기산을 분석한 결과 quinic acid, citric acid 및 malic acid가 주요 유기산으로 특히 quinic acid가 많이 검출되었으며, 산지별로는 malic acid의 함량차이를 나타내었다고 보고하여 본 실험의 결과와 유사한 결과였 다.

\section{후숙 참다래의 총페놀 함량 및 플라보노이드 함량}

건조 후 마쇄된 참다래를 $80 \%$ 에탄올로 추출한 후 총페 놀 함량 과 총플라보노이드 함량을 측정한 결과는 Fig. 1 과 같다. 총페놀 과 총플라보노이드 함량은 $365 \mathrm{mg}$ 과 140 $\mathrm{mg} / 100 \mathrm{~g} \mathrm{DW}$ (dried weight)으로 Jin 등(32)은 참다래의 $80 \%$ 에탄올 추출물에서 총페놀 함량을 $316 \mathrm{mg} / 100 \mathrm{~g}$ 으로 보고 하여 본 실험의 결과와 유사하였다. 반면에, Park 등(33)은 7종류 참다래 에탄올 추출물의 총페놀 함량을 4.18 14.48 $\mathrm{mg} / 100 \mathrm{~g}$ 으로 보고하여 본 실험의 결과보다 높은 함량을 보고하였다. 흥미롭게도 플라보노이드 함량은 총페놀량의

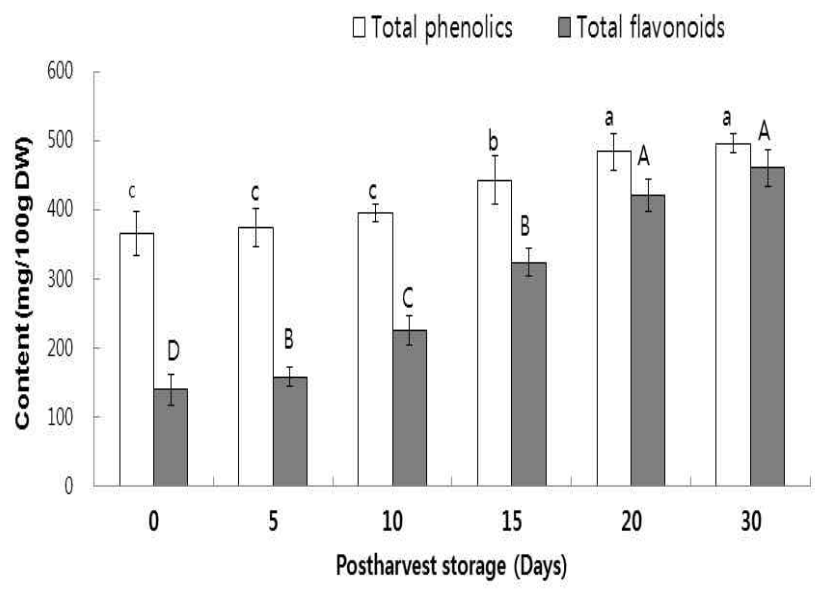

Fig. 1. Total phenolics and flavonoids contents of kiwifruit during postharvest storage.

Means in a column followed by the same letter are not significantly different $(\mathrm{p} \leq 0.05)$ by Duncan's test. 
$35 \%$ 에 해당되었으나 후숙 기간이 길어질수록, 특히 20 일 이후부터는 유사한 정도의 함량을 보였으며 총페놀 함량도 20 일 이후에 증가폭이 컸다(Fig. 1). Tavarini 등(9)은 참다래 의 총페놀 성분이 $0^{\circ} \mathrm{C}$ 에서 2 달간 저장 시 변화가 없었으나 $25^{\circ} \mathrm{C}$ 에서 2 3주 보관 만 으로도 크게 증가하는 것을 보고하 였으며 이는 본 연구와 유사한 결과로 참다래를 포함한 과실이나 채소 등 의 총페놀 함량은 저장 조건과 기간에 따라 크게 좌우되는 것을 알 수 있다(34). 페놀류 화합물은 과일, 채소, 허브 등의 식물계에 널리 분포되어 있으며 항노 화, 항암, 혈중 콜레스테롤 농도 감소, 골다공증 개선 등의 효과가 우수한 것으로 보고되고 있다 $(9,10)$. 또한 폴리페놀 화합물은 항산화 활성과 밀접한 관계가 있는데 참다래에는 pyrogallol, quercetin, ferulic acid, gallic acid 등이 주된 폴리 페놀 성분으로 존재 하는 것으로 알려져 있다 $(5,35)$.

후숙 참다래의 DPPH 소거능, 아질산염소거능 과 Tyrosinase 억제효과

열수추출물 $(25 \mathrm{mg} / \mathrm{mL})$ 을 이용하여 DPPH radical 소거활 성(항산화효과), 아질산염 소거능 및 tyrosinase 효소억제 (미백효과)를 측정하였다(Fig. 2). DPPH 소거능은 DPPH radicalo 이 항산화 활성을 갖는 물질과 반응하면 짙은 보라색 이 탈색되어 흡광도가 감소하는 원리를 이용하여 측정하는 데 방법이 간단하고 단시간 내에 많은 시료의 항산화능을 측정할 수 있어 널리 이용되고 있다. 열수추출물 첨가 농도 가 증가함에 따라 점차적으로 DPPH radical 소거활성 역시 농도 의존적으로 증가하는 경향을 나타내었으며, 추출물 $1.5,3.0,6.2,12.5$ 및 $25.0 \mathrm{mg} / \mathrm{mL}$ 의 농도로 첨가하였을 때는 $14.2,25.9,42.2,65.7$ 및 $87.5 \%$ 의 DPPH radical 소거활성을 각각 보였다(data no shown). Chung 등과 Park 등 $(5,35)$ 은 한국산 참다래 열수 추출물의 DPPH radical 소거능을 측정 한 결과 $1.5 ~ 25.0 \mathrm{mg} / \mathrm{mL}$ 의 범위에서 농도 의존적으로 소거

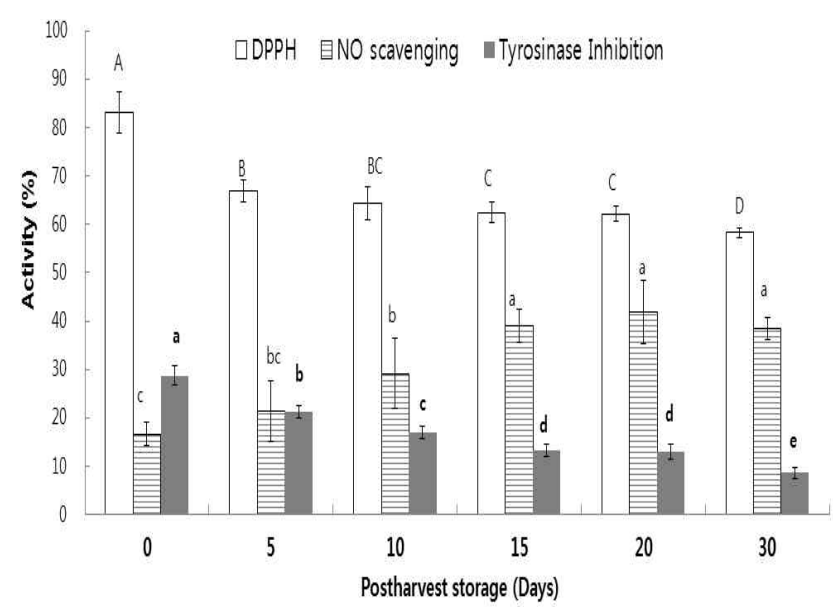

Fig. 2. DPPH or NO scavenging activity and tyrosinase inhibition of kiwifruit during postharvest storage.

Means in a column followed by the same letter are not significantly different $(\mathrm{p} \leq 0.05)$ by Duncan's test.
능이 증가하여 $25 \mathrm{mg} / \mathrm{mL}$ 에서는 $86.7 \%$ 의 소거활성을 나타 내었다고 보고하였고 본 실험에서도 DPPH radical 소거능 이 농도 의존적으로 증가하였다. 참다래는 후숙 기간이 경 과함에 따라 DPPH 소거효능이 감소하였는데, DPPH 소거 활성은 $83 \%$ 에서 5 일 이후에는 $62 \%$ 로 떨어져 20 일 까지 변화가 적다가 30 일째 $58 \%$ 로 더욱 낮아졌다. 본 연구결과 는 Tavarini 등(9)의 보고 내용과 유사하며, 저장 중 참다래 의 항산화효과가 총페놀 함량 등에 영향을 받기보다는 vitamin C 함량에 크게 좌우되며 참다래의 항산화 효과는 수확 직후가 가장 높고 점점 저장기간 약하게 줄어드는 경향이 있다고 보고하였다.

육가공품 제조 시 대부분 사용되는 아질산염은 육색의 발색 및 안정화, Clostridium botulinum균의 성장 억제, 풍미 개선 등의 역할을 하지만 과다 섭취할 경우에는 단백질 식품에 존재하는 아민류와 반응하여 발암물질인 nitrosamine 을 생성 한다(36). 니트로사민의 생성인자인 아질산염을 분해하는 효과를 측정하기 위해 아질산염 소거능을 측정 하였다(Fig. 2). 참다래는 후숙 기간이 경과함에 따라 아질 산염 소거능이 점진적으로 증가 하였는데, 아질산염 소거 활성은 $16.5 \%$ 에서 5 일에는 $21 \%$ 로 증가, 10 일째에는 $30 \%$, 15 일 30 일 까지 $40 \%$ 를 유지하였다. 아질산염은 페놀성 물 질에 의해 분해되어 nitroso화 반응이 억제된다고 보고되고 있고(37), Fig. 1에서 보이듯이, 후숙 기간이 높을수록 총페 놀 함량이 후숙 초기의 참다래에 함유되어 있는 총 페놀 함량보다 높아 높은 아질산염 소거능을 보인 것으로 사료된 다.

Tyrosinase는 피부에 침착되는 색소인 멜라닌의 생합성 에 관여하는 주요 효소로 식품업계 및 화장품업계에서는 미백제 개발을 위해 천연물 유래 tyrosinase 저해제에 대한 연구가 활발히 진행되고 있다. 후숙 기간별 tyrosinase 저해 능 을 조사한 결과(Fig. 2), 후숙 기간이 경과함에 따라 tyrosinase 저해능이 점진적으로 감소 하였는데, 저해 활성 은 $28.7 \%$ 에서 10 일에는 $16 \%$ 로 감소, 15 20일째에는 $13 \%$, 30 일에는 $8 \%$ 까지 크게 낮아졌다. Tyrosinase 저해능 패턴 은 항산화효과인 DPPH 소거능과 유사(Fig. 2) 하며 이는 tyrosinase 저해능이 항산화 효과와 더블어 총페놀량 보다는 비타민 $\mathrm{C}$ 함량과 더 직접적으로 연관 된다고 보여 진다. 본 연구결과는 Tavarini 등(9) 과 Gil 등(38)의 보고 내용과 유사하며, 참다래는 다른 과실 대비 비교적 높은 비타민 $\mathrm{C}$ 함량과 낮은 페놀 화합류를 함유하고 있어 항산화 효과와 미백 효과가 비타민 C 와 강하게 농도 의존적으로 관련성을 보인다고 보고 하였다.

\section{후숙 참다래의 Actinidin 함량과 단백질 분해효과}

후숙 기간별 참다래 분말을 이용해 조효소를 추출 후 단백질함량을 Protein assay kit를 이용해 측정하였다. 조효 소액을 SDS-PAGE 분석을 통해 참다래의 주요 단백질 분해 
효소인 actinidin을 정량, 이들의 단백질 분해력을 succinlyated casein으로 측정하였다(Fig 3).

후숙 기간별 참다래 분말의 단백질 함량은 초기에 35 $\mathrm{mg} / \mathrm{g}$ 에서 10 일에 $40 \mathrm{mg} / \mathrm{g}, 20$ 30일에는 $45 \mathrm{mg} / \mathrm{g}$ 으로 후숙 기간이 길수록 단백질 함량도 점차 증가하였다(data not shown). 이는 Rho 등(39) 과 Koak 등(40)의 보고와 유사하였 는데, 일반적으로 과실은 후숙 기간에 의해 단백질 함량이 증가되는데 다른 과실 인 포도, 사과 배 보다 참다래 에서

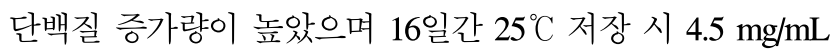
에서 $5.0 \mathrm{mg} / \mathrm{mL}$ 으로 증가 되었다고 보고하였다, 효소 추출 액을 SDS-PAGE로 분석한 결과, 기존에 보고된 자료에 따 라 참다래에 함유된 cysteine proteases로 각 $17 \mathrm{kDa}, 23 \mathrm{kDa}$, $31 \mathrm{kDa}$ 분자량의 actinidin 위치를 확인 하였고 이들의 밀도 를 측정해 전체 함량을 구하였다(Fig. 3). 후숙 기간이 경과 됨에 따라 actinidin의 함량도 점차 증가되는 것으로 나타났 는데(Fig. $3 \mathrm{~A})$, 특히 $31 \mathrm{kDa}$ 와 $17 \mathrm{kDa}$ 크기의 효소량 증가가 두드러졌다. 또한 효소 추출액에 함유된 액티니딘 함량은 전체 단백질량의 30 35\%를 차지하였으며 초기에 $12 \mathrm{mg} / \mathrm{g}$ 에서 10 일까지 $13 \mathrm{mg} / \mathrm{g}$ 으로 약간 증가하였고 20 일 이후부 터는 $16 \mathrm{mg} / \mathrm{g}$ 으로 효소 함량이 크게 증가하였다. 후숙 기간 이 길수록 단백질 함량도 점차 증가하여 단백질 증가 양상 과 유사하였다. 이에 따른 카세인 단백질을 이용한 단백질 분해효능도 유사한 경향을 보였는데, 초기 10 일까지는 47 75 U으로 약간 증가하였고 20일 이후부터는 140 153 $\mathrm{U}$ 으로 크게 증가하여 이후 유사한 효능을 보이는 것으로 나타났다(Fig. $3 \mathrm{~B})$. 위의 결과는 Koak 등(40) 의 보고와 유사 하였으며, 단백질 분해효소 및 이의 효능은 다른 과실인

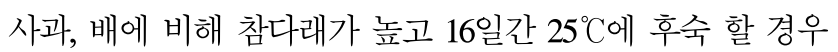
증가 되었다고 보고하였다, 위의 결과를 종합하면, 참다래 의 단백질 분해효소와 효능을 후숙 기간이 길수록 증가되며 특히 $25^{\circ} \mathrm{C}$ 에서 보관 시 20 일 이후부터 증가
량이 큰 것을 알 수 있었다.

\section{후숙 참다래의 관능평가}

후숙 기간별 참다래의 외관(appearance), 풍미(flavor), 씹 힙성(chewiness), 이취성 또는 떫음(off-taste, stringency)과 전체적 기호도(overall acceptibility) 관련해서 관능검사를 실시한 결과는 Table 5 와 같다. 전체 9점 채점방식으로 관능 검사를 실시한 후 처리방법간의 차이를 $5 \%$ 유의수준 범위 내에서 사후 검정하였다. 외관과 씹힘성, 이취성에 있어서 는 후숙 기간이 길수록 높았는데 풍미를 제외하고는 특히 20 일째가 선호도가 가장 높았으며 흥미롭게도 30 일 째에는 오히려 선호도가 떨어지는 경향을 보였다. 특히 이취성은 참다래의 떫은맛에 관한 선호도로 30 일 째에는 과실 후숙 진행이 지나쳐서 이취성을 유발하는 떫은맛이 낮아도 오히 려 전체적인 선호도를 떨어뜨리는 경향이 있는 것으로 여겨 진다. 씹힘성도 유사한 경향으로 적당한 씹힘성은 좋으나 너무 물러지는 경향은 선호도를 낮추는 것으로 간주되었 다. 전체적인 기호도는 전반적으로 각 항목간 밀접한 영

Table 5. Sensory evaluation of kiwifruit during postharvest storage

\begin{tabular}{cccccc}
\hline $\begin{array}{c}\text { Storage periods } \\
\text { (days) }\end{array}$ & Appearance & Flavor & Chewiness & $\begin{array}{c}\text { Off-taste } \\
\text { (stringency) }\end{array}$ & $\begin{array}{c}\text { Overall } \\
\text { acceptibility }\end{array}$ \\
\hline 0 & $5.42 \pm 0.21^{\mathrm{c})}$ & $5.82 \pm 0.25^{\mathrm{d}}$ & $5.83 \pm 0.15^{\mathrm{d}}$ & $5.85 \pm 0.15^{\mathrm{e}}$ & $5.85 \pm 0.05^{\mathrm{c}}$ \\
5 & $6.00 \pm 0.15^{\mathrm{bc}}$ & $6.00 \pm 1.05^{\mathrm{c}}$ & $6.00 \pm 0.02^{\mathrm{c}}$ & $6.62 \pm 0.25^{\mathrm{b}}$ & $5.85 \pm 0.05^{\mathrm{c}}$ \\
10 & $6.43 \pm 0.32^{\mathrm{bc}}$ & $6.81 \pm 0.45^{\mathrm{b}}$ & $6.24 \pm 0.09^{\mathrm{b}}$ & $6.63 \pm 0.29^{\mathrm{b}}$ & $6.00 \pm 0.15^{\mathrm{bc}}$ \\
15 & $6.82 \pm 0.31^{\mathrm{b}}$ & $6.43 \pm 0.15^{\mathrm{bc}}$ & $6.21 \pm 0.21^{\mathrm{b}}$ & $6.40 \pm 0.15^{\mathrm{c}}$ & $6.84 \pm 0.25^{\mathrm{b}}$ \\
20 & $7.21 \pm 1.15^{\mathrm{a}}$ & $7.42 \pm 1.05^{\mathrm{a}}$ & $7.65 \pm 0.12^{\mathrm{a}}$ & $6.80 \pm 0.22^{\mathrm{a}}$ & $7.21 \pm 0.25^{\mathrm{a}}$ \\
30 & $6.62 \pm 0.50^{\mathrm{bc}}$ & $7.45 \pm 1.00^{\mathrm{a}}$ & $7.12 \pm 0.25^{\mathrm{a}}$ & $6.00 \pm 0.15^{\mathrm{d}}$ & $6.25 \pm 0.25^{\mathrm{bc}}$ \\
\hline
\end{tabular}

Each value represents the man of rating by 15 judges 9-point scale (1=extremely dislike, $9=$ extremely like).

${ }^{1}$ Means in a column followed by the same letter are not significantly different $(\mathrm{p} \leq 0.05)$ by Duncan's test.
A.

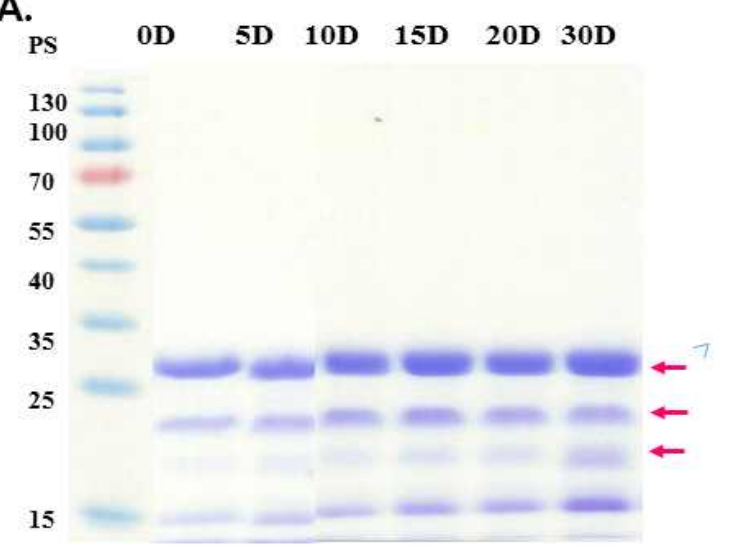

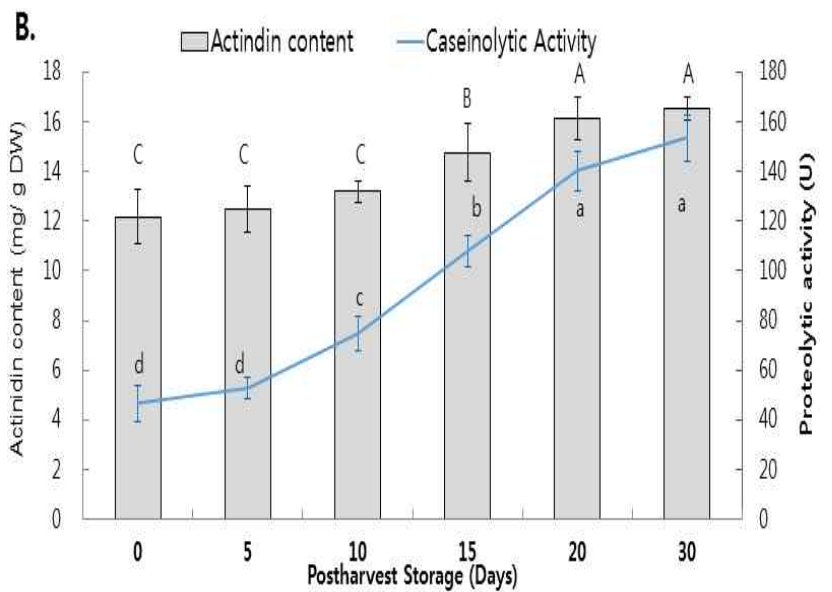

Fig. 3. SDS-PAGE analysis of actinidin extracts from kiwifruit during postharvest storage (A). Actinidin contents and proteolytic activity of kiwifruit during postharvest storage (B).

Means in a column followed by the same letter are not significantly different $(\mathrm{p} \leq 0.05)$ by Duncan's test. 
향을 미치는 것으로, 결국 20 일 째가 가장 높았으며 오히려 30 일 째에는 15 일 째 보다 낮은 것으로 나타났다(Table 5).

\section{요 약}

상온 $\left(20 \sim 25^{\circ} \mathrm{C}\right)$ 에서 후숙 $(0$ 일 30일)된 참다래의 품질 및 영양성분 함량분석을 수행하였고 최적 후숙 기간을 구명하 기 위해 항산화활성, 단백질 분해능과 관능평가를 수행하 였다. 기간별 후숙된 참다래의 품질은 경도와 산도가 20 일 이후부터 급격히 감소되는 경향을 보였고 식이섬유, 특히 수용성 식이섬유는 20 일 이후에 함량이 크게 증가 하였으 며 유리당과 유기산 함량도 대체적으로 20 일 이후에 뛰게 각 증가와 감소하는 경향을 보였다. 총페놀과 총플라보노 이드 함량은 20 일 이후에 함량이 유의하게 높았고 아질산 염 소거능도 이와 유사하게 증가하는 경향을 보였다. 또한 DPPH radical 소거능을 통한 항산화 효과와 tyrosinase 억제 능을 이용한 미백효과는 기간이 길어질수록 감소하였는데 이는 비타민 C 함량 패턴과 유사하였다. 참다래에 함유된 단백질 분해효소 actinidin을 SDS-PAGE 분석을 통해 확인 하였고 함량과 이의 효능을 조사한 결과 후숙 기간이 경과 됨에 따라 actinidin의 함량 과 단백질 분해능도 점차 증가하 였으며 15 20일 이후에 급격히 높아지는 것을 확인 하였다. 후숙 기간별 참다래의 관능평가도 수행 하였는데, 20 일 째 가 선호도가 가장 높았으며 흥미롭게도 30 일 째에는 오히 려 선호도가 떨어지는 경향을 보였다. 현재까지 저온 저장 된 참다래의 상온 보관시 최적 후숙 기간에 관한 연구는 미흡한 실정으로 본 연구 결과는 소비자에게 저장 보관된 참다래의 소비 및 섭취에 있어서 도움이 될 것으로 생각된다.

\section{감사의 글}

본 연구는 농촌진흥청 국립원예특작과학원의 신품종배 이용촉진 사업 II 연구비(과제번호: PJ01002403)와 전라남 도 농업기술원 전남특용작물의 기능성 성분 및 효능평가 연구과제 및 로 이루어진 결과이며, 이에 감사 드립니다

\section{References}

1. Jeong JA, Kwon SH, Kim YJ, Shin CS, Lee CH (2007) Investigation of antioxidative and tyrosinase inhibitory activities of the seed extracts. Korean J Plant Res, 20, 177-184

2. Kim GH, Lee YS, Jung JS, Hur JS, Koh YJ (2013) Optimal spray time, interval and number of preventive fungicides for the control of fruit rots of green and gold kiwifruit cultivars. Res Plant dis, 19, 1-6

3. Rho JH, Kim YB, Kil BI (2002) The effect of bulking agent on quality of kiwifruit powder in the process of domestic kiwifruit tenderizer. Korean J Food Sci Technol, $34,805-810$

4. Jin DE, Kim HJ, Jeong JH, Jo YN, Kwon OJ, Choi SG, and Heo HJ (2014) Nutritional components of zespri green kiwi fruit (Actinidia delicosa) and neuronal cell protective effects of $\mathbf{n}$-hexane fraction. Korean J Food Sci Technol, 46, 369-374

5. Chung, HJ, Kim CJ, Choi YS (2015) Comparison of antioxidant and nitrite scavenging activities of different colored kiwis cultivated in Korea. J Korean Soc Food Cult, 30, 220-226

6. Pastorello EA, Conti A, Pravettoni V, Farioli L, Rivolta F, Ansaloni R, Ispano M, Incorvaia C, Giuffrida MG, Ortolani C (1998) Identification of actinidin as the major allergen of kiwi fruit. J Allergy Clin Immunol, 101, 531-537

7. Nam SH, Walsh MK, Yang, KY (2006) The enzymatic properties of actinidin from Kiwifruit. Food Sci Biotechnol, 15, 453-457

8. Nishiyama I, Yamashita Y, Yamanaka M, Shimohashi A, Fukuda T, Oota T (2004). Varietal difference in vitamin $\mathrm{C}$ content in the fruit of kiwifruit and other Actinidia species. J Agric Food Chem, 52, 5472-5475

9. Tavarini S, Degl'Innocenti E, Remorini D, Massai R, Guidi L (2008) Antioxidant capacity, ascorbic acid, total phenols and carotenoids changes during harvest and after storage of Hayward kiwifruit. Food Chemistry, 107, 282-288

10. Krupa T, Latocha P, Liwin'ska A (2011). Changes of physicochemical quality, phenolics and vitamin $\mathrm{C}$ content in hardy kiwifruit (Actinidia arguta and its hybrid) during storage. Sci Hortic, 130, 410-417

11. Fisk CL, McDaniel MR, Strik BC, Zhao Y (2006) Physicochemical, sensory and nutritive qualities of hardy Kiwifruit (Actinidia arguta 'Ananasnaya') as affected by harvest maturity and storage. J Food Sci, 71, 204-210

12. Antunes MDC, Sfakiotakis EM (2002) Chilling induced ethylene biosynthesis in 'Hayward' kiwifruit following storage. Sci Hortic, 92, 29-39

13. Valente M, Prades A, Laux D (2013) Potential use of physical measurements including ultrasound for a better mango fruit quality characterization. J Food Eng, 116, $57-64$ 
14. AOAC (1990) Official Methods of Analysis. 15th ed, Association of Official Analytical Chemists, Washington DC, USA, p 8-35

15. Ramulu P, Rao PU (2003) Total, insoluble and soluble dietary fiber contents of Indian fruits. J Food Composit Anal, 16, 677-685

16. Choi JH, Jang JG, Park KD, Park MH, Oh SK (1981) High performance liquid chromatographic determination of free sugars in ginseng and its products. Korean J Food Sci Technol, 13, 107-113

17. Medicott AP, Thompson AK, Anthong KT (1985) Analysis of sugars and organic acids in ripening mango fruits by high performance liquid chromatography. J Sci Food Agric, 36, 561-566

18. Cui T, Nakamura K, Ma L, Li JZ, Kayahara H (2005) Analyses of arbutin and chlorogenic acid, the major phenolic constituents in Oriental pear. J Agric Food Chem, 53, 3882-3887

19. Boo HO, Lee HH, Lee JW, Hwang SJ, Park SU (2009) Different of total phenolics and flavonoids, radical scavenging activities and nitrite scavenging effects of Momordica charantia L. according to cultivars. Korean J Medi Crop Sci, 17, 15-20

20. Blios MS (1958) Antioxidant determination by the use of a stable free radical. Nature, 26, 1198-1204

21. Kato H, Le IE, Chuyen NV, Kim SB, Hayase F (1987) Inhibition of nitrosamine formation by nondialyzable melanoidins. Agric Biol Chem, 51, 1333-1338

22. Soares PAG, Vaz AFM, Correia MTS, Pessoa A, Carneiro-da-Cunha, MG (2012) Purification of bromelain from pineapple wastes by ethanol precipitation. Sep Purif Technol, 98, 389-395

23. Ha M, Bekhit AED, Carne A, Hopkins DL (2012) Characterization of commercial papain, bromelain, actinidin and zingibain protease preparations and their activities toward meat proteins. Food Chem, 134, 95-105

24. Jeong CH, Lee WJ, Bae SH Choi SJ (2007) Chemical components and antioxidative activity of Korean gold kiwifruit. J Korean Soc Food Sci Nutr, 36, 859-865

25. Kim JM, Ko YS (1997) Changes in chemical components of Korean kiwifruit (Actinidia deliciosa) by storage temperature. Korean J Food Sci Technol 29, 618-622

26. Park YS, Lim DG Heo KG (2009) Changes in the fruit quality of organic and low-level agro chemical-grown kiwifruit during storage. Korean J Food Preserv, 16, 327-332

27. Lee SE, Kim DM, Kim KH, Rhee C (1989) Several physico-chemical characteristics of kiwifruit (Actinidia chinensis Planch.) depend on cultivars and ripening stages. Korean J Food Sci Technol, 21, 869-875

28. Leontowicz H, Leontowicz M, Latocha P, Jesion I, Park YS, Katrich E, Barasch D, Nemirovski A, Gorinstein S (2016) Bioactivity and nutritional properties of hardy kiwi fruit Actinidia arguta in comparison with Actinidia deliciosa 'Hayward' and Actinidia eriantha 'Bidan' Food Chem, 196, 281-291

29. Matsumoto S, Obara T, Luh BS (1983) Changes in chemical constituents of kiwifruit during postharvest ripening. J Food Sci, 48, 607-611

30. Barboni T, Cannac M, Chiaramonti N (2010) Effect of cold storage and ozone treatment on physicochemical parameters, soluble sugars and organic acids in Actinidia deliciosa. Food Chem, 121, 946-951

31. Youn KS, Choi YH (1998) The quality characteristics of dried kiwifruit using different drying methods. Food Engineering progress, 2, 49-54

32. Jin DE, Kim HJ, Jeong JH, Jo YN, Kwon OJ, Choi SG, Heo HJ (2014) Nutritional components of zespri green kiwi fruit (Actinidia delicosa) and neuronal cell protective effects of the n-hexane fraction. Korean J Food Sci Technol, 46, 369-374

33. Park YS, Namiesnik J, Vearasilp K, Leontowicz H, Leontowicz M, Barasch D, Nemirovski A, Trakhtenberg S, Gorinstei S (2014) Bioactive compounds and the antioxidant capacity in new kiwi fruit cultivars. Food Chem, 165, 354-361

34. Kalt W (2005) Effects of production and processing factors on major fruit and vegetable antioxidants. J Food Sci, 70, 11-19

35. Park YS, Namiesnik J, Vearasilp K, Leontowicz H, Leontowicz M, Barasch D, Nemirovski A, Trakhtenberg S, Gorinstei S (2014) Bioactive compounds and the antioxidant capacity in new kiwi fruit cultivars. Food Chem, 165(15), 354-361

36. Park YB (2005) Determination of nitrite-scavenging activity of seaweed. J Korean Soc Food Sci Nutr, 34, 1293-1296

37. Lim JA, Yun BW, Baek SH (2007) Antioxidative activity and nitrite scavenging ability of methanol extract from Salvia plebeia R. Br. Korean J Medicinal Crop Sci, 15, 183-188

38. Gil MI, Aguayo E, Kader AA (2006) Quality changes and nutrient retention in fresh-cut versus whole fruits during storage. J Agric Food Chem, 54, 4284-4296 
39. Rho JH, Lee SH, Kwon HK (2000) The quality change of fruits containing proteolytic activity during storage and lyophilization. J Korean Soc Food Sci Nutr, 29, 1057-1061
40. Koak JH, Kim HS, Choi YJ, Baik MY, Kim BY (2011) Characterization of a protease from over-matured fruits and development of a tenderizer using an optimization technique. Food Sci Biotechnol, 20, 485-490 